\title{
Aroui minusetosus, a new species of Scopelocheiridae from Korea (Crustacea, Amphipoda, Lysianassoidea)
}

\author{
Tae Won Jung', Charles Oliver Coleman', Seong Myeong Yoon ${ }^{2}$ \\ I Museum für Naturkunde Berlin, Berlin 10115, Germany 2 Department of Biology, Chosun University, \\ Gwangju 16452, Korea \\ Corresponding author: Seong Myeong Yoon (smyun@chosun.ac.kr)
}

$\frac{\text { Academic editor: A. Myers | Received 3 August } 2017 \text { | Accepted } 11 \text { September } 2017 \text { | Published } 4 \text { October } 2017}{\text { http://zoobank.org/BC9204C4-8672-4831-AD4F-6D8683DF69AE }}$

Citation: Jung TW, Coleman CO, Yoon SM (2017) Aroui minusetosus, a new species of Scopelocheiridae from Korea (Crustacea, Amphipoda, Lysianassoidea). ZooKeys 706: 17-29. https://doi.org/10.3897/zookeys.706.20007

\begin{abstract}
A new species, Aroui minusetosus sp. n., is recorded from Korean waters with detailed description and illustrations. A new key to all known Aroui is provided. The Korean material of this scopelocheirid is readily assigned to the genus Aroui by the presence of long and distally barbed setae on the outer plate of maxilla 2. This new species is distinguished from congeners by ventrally smooth coxae 1-3 and a setose posteroventral margin of coxa 4 , the subchelate gnathopod 2 having a row of four robust setae on its posterior margin (including an elongate single locking seta), and the setation of all appendages which is less dense than in other species. This is the first record of scopelocheirid amphipods from Korean waters.
\end{abstract}

\section{Keywords}

Aroui minusetosus sp. n., amphipod, Korea, lysianassoid, Scopelocheiridae, taxonomy

\section{Introduction}

The family Scopelocheiridae was established by Lowry and Stoddart (1997) based on the synapomorphy of a strongly shortened dactylus of gnathopod 1 which is covered with various distal setae from the propodus. Simultaneously, they recognized two subgroups in this family according to the differences of the mandibular molar shape: the Scopelocheirus group, which has a columnar molar bearing a small triturative surface and the Paracallisoma group, in which the molar is a non-setose triangular flap or is absent (Lowry and Stoddart 1997). Kilgallen and Lowry (2015) reviewed the worldwide species of

Copyright Tae Won Jung et al. This is an open access article distributed under the terms of the Creative Commons Attribution License (CC BY 4.0), which permits unrestricted use, distribution, and reproduction in any medium, provided the original author and source are credited. 
Scopelocheiridae and the two subgroups mentioned by Lowry and Stoddart (1997) were ranked as subfamily level: Scopelocheirinae and Paracallisominae. The Scopelocheirinae is a small group including only eight species of three genera (Kilgallen and Lowry 2015). The genus Aroui Chevreux, 1911 included in the Scopelocheirinae is characterized from other Scopelocheiridae genera by bearing unusually long and distally barbed setae on the outer plate of maxilla 2. There are only four valid species worldwide: Aroui americana Lowry \& Stoddart, 1997 from the Gulf of Mexico and Argentina; Aroui hamatopodus Lowry \& Stoddart, 1989 from Australia; Aroui onagawae (Takekawa \& Ishimaru, 2000) from Japan; and Aroui setosus Chevreux, 1911 from the Mediterranean Sea (Chevreux 1911, Lowry and Stoddart 1997, 1989, Takekawa and Ishimaru 2000, Kilgallen and Lowry 2015). However, hitherto the Scopelocheiridae has not been recorded from Korean waters. In this study, a new scopelocheirid lysianassoid, Aroui minusetosus sp. n., is reported with detailed description and illustrations, and a key to all known species of the genus Aroui is provided.

\section{Materials and methods}

The collected specimens of lysianassids were initially fixed in $80 \%$ ethyl alcohol in the field and then preserved in 95\% ethyl alcohol after sorting in the laboratory. Specimens were stained with lignin pink before dissection. Their appendages were dissected in petri dishes or excavated microscopic slides filled with mixed solution of glycerolethanol using dissecting forceps and needles under a stereomicroscope (Leica M205), and mounted onto temporary slides using glycerol. To prepare illustrations, pencil drawings were made under a light microscope (Leica DMLB) with the aid of a drawing tube. These were then scanned, digitally inked, and arranged on digital plates using the methods described by Coleman (2003, 2009). Definition of the term for 'seta' and its types follows that of Watling (1989). Examined specimens were deposited in the collection of the National Institute of Biological Resources (NIBR) of Korea.

\section{Systematic account}

Order Amphipoda Latreille, 1816

Superfamily Lysianassoidea Dana, 1849

Family Scopelocheiridae Lowry \& Stoddart, 1997

Korean Name: Teol-son-gin-pal-yeop-sae-u-gwa, new

\section{Subfamily Scopelocheirinae Kilgallen \& Lowry, 2015}

Korean Name: Teol-son-gin-pal-yeop-sae-u-a-gwa, new 


\section{Genus Aroui Chevreux, 1911}

Korean Name: Teol-son-gin-pal-yeop-sae-u-sok, new

\section{Aroui minusetosus sp. $\mathbf{n}$.}

http://zoobank.org/0DE2B629-ED1F-46EB-883C-EFDF8196AC78

Figs $1-4$

Korean Name: Teol-son-gin-pal-yeop-sae-u, new

Type locality. Somaemul Island $\left(34^{\circ} 37.656^{\prime} \mathrm{N}, 128^{\circ} 32.467^{\prime} \mathrm{E}\right.$, depth $\left.52 \mathrm{~m}\right)$, Gyeongsangnam-do, South Korea.

Material examined. Holotype: adult male, $4.3 \mathrm{~mm}$, NIBRIV0000806536. Paratype: one male, $3.0 \mathrm{~mm}$, NIBRIV0000807161; all dissected appendages and remain bodies of type specimens were preserved in $95 \%$ ethanol; collected from the type locality at 12 May 2012, by grab sampling. These specimens were provided by Prof. H.-Y. Soh.

Etymology. The composite epithet of the specific name of minusetosus is a combination of the Latin minus and setosus, referring to having less setose appendages.

Diagnosis. Head eyes ovoid, ommatidia large. Antennae calceoli absent. Mandible with columnar molar process, elevated, triturative surface weakly developed. Maxilla 1 inner plate with plumose setae along medial margin and apex; outer plate with toothed setae apically in 7/4 arrangement; palp article 3 swollen distally, with dentate setae apically. Maxilla 2 inner plate longer than outer plate; outer plate with marginal and submarginal rows composed of barbed and simple setae apically (all setae extremely elongate). Coxae 1-3 not densely setose ventrally; coxa 4 setose posteroventrally. Gnathopod 1 scopelocheirin form; coxa 1 subtriangular; propodus slightly longer than carpus, with rows of long setae forming tuft distally, palm absent; dactylus extremely reduced, anchored at posterodistal corner. Gnathopod 2 propodus subrectangular, with four robust setae posterodistally (distal locking seta extremely elongate), palm nearly transverse, with small protrusion. Pereopods 3-4 moderately developed. Pereopod 5 coxa anterior lobe slightly expanded downward than posterior lobe; basis shorter than coxa, wider than long, anterior margin distal $2 / 3$ length with many elongate robust setae marginally and minute setae submarginally, posterior lobe largely expanded; ischium and merus lined with many simple and robust setae anteriorly; merus posterior margin expanded, with slender setae on distal $2 / 3$ length, posterodistal corner produced (reaching $1 / 3$ length of merus) with robust seta. Pereopod 6 longer and slender than pereopod 5; merus about half as long as basis, expanded posteriorly; carpus rectangular, $1.2 \times$ as long as merus; propodus linear, $1.1 \times$ as long as carpus, with simple long setae on distal half of posterior margin. Pereopod 7 slightly longer and stouter than pereopod 6; basis longer than that of pereopod 6; merus posterior lobe weaker, but setae stouter than those of pereopod 6; carpus and propodus stouter than those of pereopod 6. Epimeron 1 anteroventral corner angulate with one robust seta, posterior margin round and with small notches. Epimera 2-3 expanded and with facial setae 
anteroventrally, posterior margins lined with small notches. Urosomite 1 with deep dorsal depression and mid-dorsal carina. Uropods 1-2 peduncles longer than rami, with robust setae on lateral and medial margins; outer rami with lateral robust setae only. Uropod 3 shorter than uropod 2; outer ramus bi-articulate; inner ramus not reaching distal end of proximal article of outer ramus in position. Telson cleft about $70 \%$, each lobe with deep apical notch bearing one pair of robust and sensory seta, with one robust seta and one pair of sensory setae dorsolaterally.

Description of holotype male. Head. Lateral cephalic lobes expanded anteriorly, round; eyes ovoid, ommatidia large (Fig. 1B).

Antenna 1 (Fig. 1C, D) $0.6 \times$ as long as antenna 2, as long as head to pereonite 1 combined; peduncular article 1 swollen anteriorly; accessory flagellum 3-articulate; flagellum article 1 distinctly elongate; calceoli absent.

Antenna 2 (Fig. 1E) $0.3 \times$ as long as body; peduncular articles moderately developed; flagellum 21-articulate; calceoli absent.

Upper lip (Fig. 1F) epistome concave, separated from upper lip; upper lip slightly produced, rounded.

Lower lip (Fig. 1G) with developed mandibular processes

Mandible (Fig. 1H-J) incisor smooth but bearing blunt denticles on both sides; lacinia mobilis present on left mandible only, stemmed, expanded distally, with irregularly cusped blade; three small raker setae present on both mandibles, patch setules between raker setae and molar processes absent; molar process columnar, elevated, with triturative, rather smooth surface; lateral setigerous crest absent; palp attached midway, 3-articulate; article 2 longest, swollen anteriorly, with an oblique row of ten setae distally; article 3 weakly falcate, $0.7 \times$ as long as article 2 , with twelve setae from middle of inner margin to apex.

Maxilla 1 (Fig. 2A, B) inner plate narrowing distally, not short, setose, with nine plumose setae along medial margin and apex; outer plate with eleven toothed setae apically in 7/4 arrangement and with several setae submarginally; palp bi-articulate, distal article swollen distally, apical margin oblique, with six mono-dentate short setae, one multi-dentate elongate seta, and one plumose seta.

Maxilla 2 (Fig. 2C) each plate broad; inner plate $1.3 \times$ as long as outer plate, with two rows of simple and plumose setae along distal half of medial and apical margins; outer plate with one marginal and one submarginal rows composed of barbed and simple setae apically (all setae extremely elongate).

Maxilliped (Fig. 2D) inner plate with one mediodistal row of plumose setae, apex with three nodular setae; outer plate well developed, subovoid, apex reaching the middle of palp article 3 , lined with 13 nodular setae, eleven plumose setae, and two pairs of simple setae along mediodistal margin; palp 4-articulate, article $22.0 \times$ as long as article 1 , article $40.7 \times$ as long as article 3 , with one short apical seta.

Pereon. Gnathopod 1 (Fig. 2E-G) scopelocheirin form; coxa 1 large, subtriangular, expanded distally, round ventrally; basis $0.9 \times$ as long as coxa, anterior margin straight, lined with short setae, posterior margin slightly expanded; ischium $0.4 \times$ as long as basis; carpus elongate, $0.7 \times$ as long as basis; propodus subrectangular, $1.1 \times$ as long 


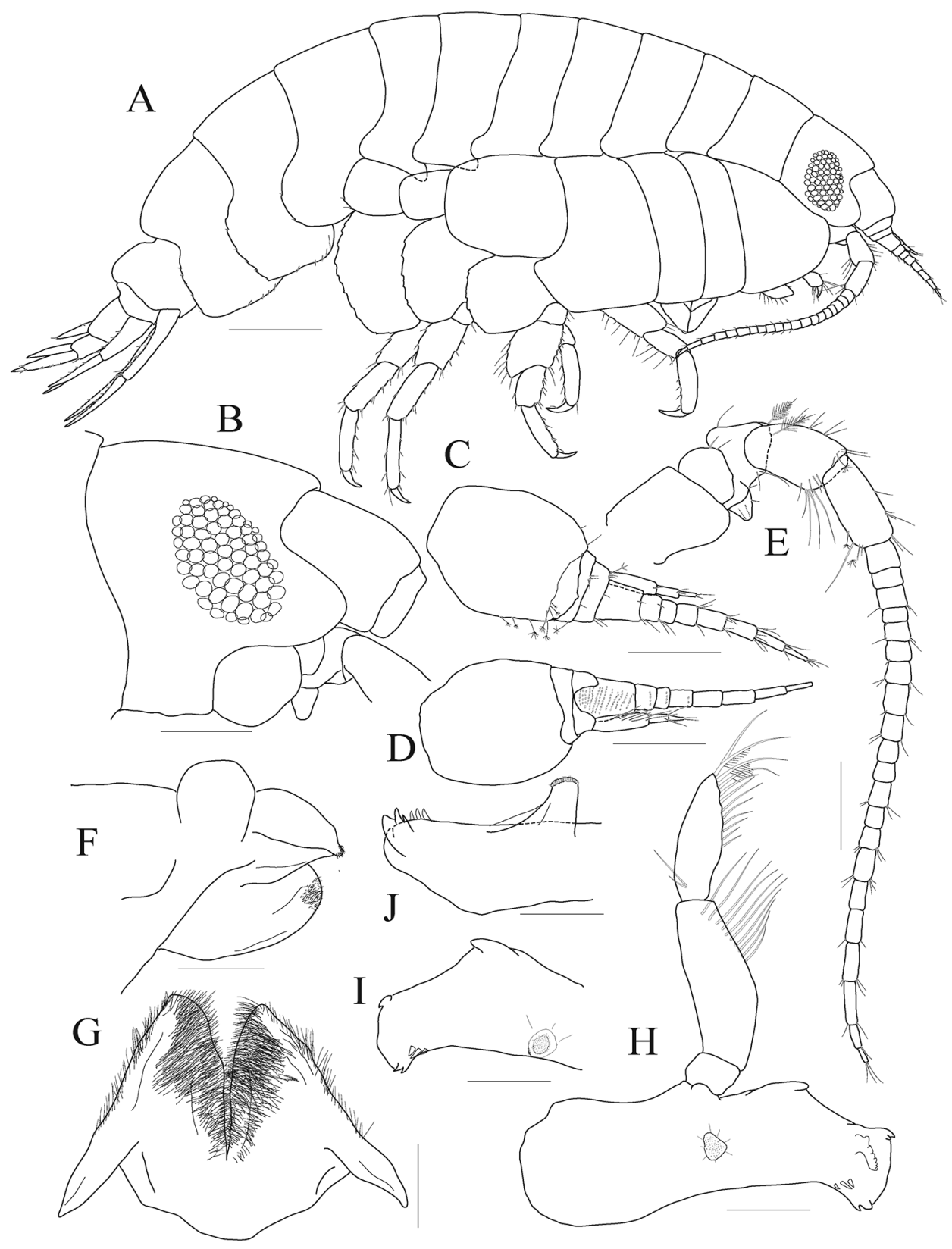

Figure I. Aroui minusetosus sp. n., holotype male, NIBRIV0000806536, $4.3 \mathrm{~mm}$. A habitus B head $\mathbf{C}$ antenna 1, lateral $\mathbf{D}$ antenna 1, medial $\mathbf{E}$ antenna $2 \mathbf{F}$ upper lip, lateral $\mathbf{G}$ lower lip $\mathbf{H}$ left mandible I, J right mandible. Scale bars: $0.1 \mathrm{~mm}(\mathbf{F}-\mathbf{J}), 0.2 \mathrm{~mm}(\mathbf{B}-\mathbf{E}), 0.5 \mathrm{~mm}(\mathbf{A})$. 


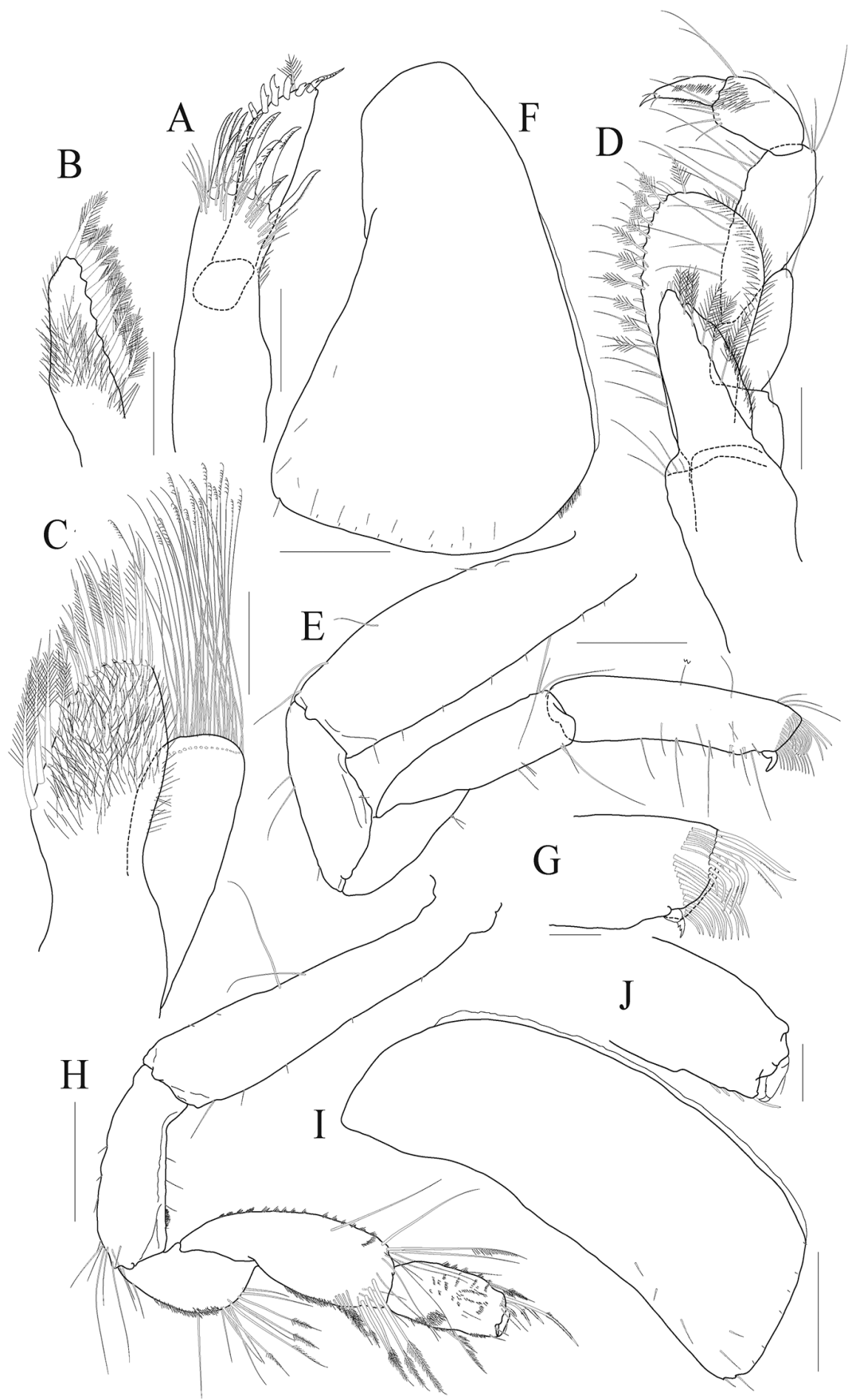

Figure 2. Aroui minusetosus sp. n., holotype male, NIBRIV0000806536, $4.3 \mathrm{~mm}$. A maxilla 1 B inner plate of maxilla $1 \mathbf{C}$ maxilla $2 \mathbf{D}$ maxilliped $\mathbf{E}$ gnathopod $1 \mathbf{F}$ coxa $1 \mathbf{G}$ palm and dactylus of gnathopod 1 $\mathbf{H}$ gnathopod $2 \mathbf{I}$ coxa $2 \mathbf{J}$ palm and dactylus of gnathopod 2. Scale bars $0.05 \mathrm{~mm}(\mathbf{G}, \mathbf{J}), 0.1 \mathrm{~mm}(\mathbf{A}-\mathbf{D})$, $0.2 \mathrm{~mm}(\mathbf{E}, \mathbf{F}, \mathbf{H}, \mathbf{I})$. 
as carpus, slightly curved, with one lateral and two medial rows of long setae forming tuft distally, palm absent; dactylus extremely reduced, anchored at posterodistal corner.

Gnathopod 2 (Fig. 2H-J) slender, subchelate; coxa 2 subrectangular, $2.9 \times$ as long as wide, slightly curved posteroventrally, with two small notches posteroventrally; basis $0.9 \times$ as long as coxa, slightly widened distally; ischium elongate, slightly dilated posterodistally, $0.4 \times$ as long as basis; merus $0.6 \times$ as long as ischium, round posteriorly, with many short setae and one cluster of long setae; carpus $0.6 \times$ as long as basis, anterior margin swollen, with several clusters of short setae, longest seta at anterodistal corner reaching distal end of propodus, with two rows of plumose setae posterodistally; propodus subrectangular, $0.6 \times$ as long as carpus, with four robust setae posterodistally (distal locking seta extremely elongate), palm nearly transverse, with small protrusion posterodistally; dactylus falcate, slightly beyond palm.

Pereopod 3 (Fig. 3A) stout; coxa subrectangular, $3.0 \times$ as long as wide, slightly curved and with two small notches posteroventrally; basis $0.7 \times$ as long as coxa, subtrapezoidal, somewhat expanded posterodistally; ischium elongate, $0.4 \times$ as long as basis, anterior lobe weak; merus expanded anteriorly, anterodistal corner weakly produced; carpus $0.7 \times$ as long as merus, somewhat expanded distally, with simple and robust setae on posterior margin; propodus $1.5 \times$ as long as carpus, lined with robust setae on posterior margin, with one pair of locking setae posterodistally; dactylus falcate, $0.4 \times$ as long as propodus, unguis developed.

Pereopod 4 (Fig. 3B) coxa deeper than wide, expanded posteroventrally; other articles nearly similar to those of pereopod 3 .

Pereopod 5 (Fig. 3C) coxa large, subquadrate, slightly wider than long, weakly bilobate and anterior lobe slightly expanded downward than posterior lobe, posteroventral margin oblique, lined with minute setae, with three minute notches each bearing seta; basis subovoid, smaller than coxa, wider than long, anterior margin round, with many elongate robust setae marginally and minute setae submarginally on distal $2 / 3$ length, posterior lobe largely expanded, posterodistal end reaching $1 / 4$ length of merus, margin weakly crenulate and lined with minute setae, with one row of four setae medially; ischium and merus lined with many simple and robust setae anteriorly; merus posterior margin expanded, with five slender setae distally on $2 / 3$ length, posterodistal corner produced (reaching 1/3 length of merus) with one robust seta; carpus dilated posterodistally, $0.8 \times$ as long as merus, anterior margin crenulate and lined with robust setae; propodus $1.3 \times$ as long as carpus, with single and paired robust setae on anterior margin; dactylus falcate, $0.4 \times$ as long as propodus, unguis developed.

Pereopod 6 (Fig. 3D) longer and more slender than pereopod 5; coxa subrectangular, smaller than that of pereopod 5, bilobate, anterior lobe smaller than posterior lobe, expanded downward, with three plumose setae anteriorly, posterior lobe weakly crenulate, with three plumose setae posteroventrally and minute setae on posterior margin; basis ovoid, $1.7 \times$ as long as wide, anterior margin round proximally and remains nearly straight bearing short robust setae, with one cluster of elongate and short robust setae at anterodistal corner, posterior margin well expanded, smooth, weakly crenulate, posterodistal end reaching 1/4 length of merus; merus half as long as basis, 


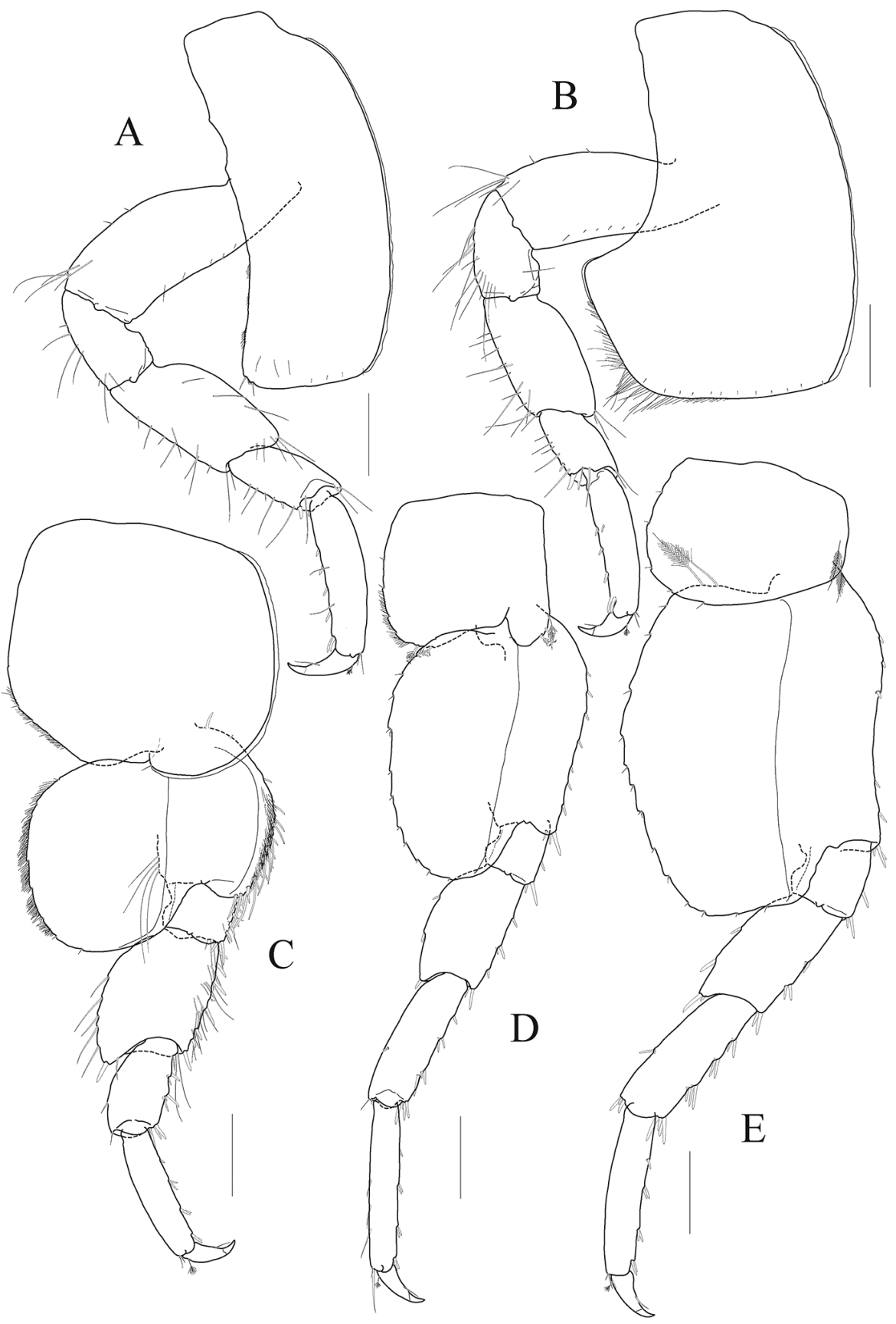

Figure 3. Aroui minusetosus sp. n., holotype male, NIBRIV0000806536, $4.3 \mathrm{~mm}$. A pereopod 3 B pereopod 4 C pereopod 5 D pereopod $6 \mathbf{E}$ pereopod 7. Scale bars $0.2 \mathrm{~mm}(\mathbf{A}-\mathbf{E})$. 
expanded posteriorly; carpus rectangular, $1.2 \times$ as long as merus; propodus linear, 1.1 $\times$ as long as carpus, with single and paired robust setae on anterior margin and simple long setae on distal half of posterior margin; dactylus falcate, $0.4 \times$ as long as propodus, unguis developed.

Pereopod 7 (Fig. 3E) $1.1 \times$ as long as and stouter than pereopod 6; coxa unilobate, with two plumose setae anteriorly, dilated and weakly crenulate posteroventrally; basis larger than that of pereopod 6, anterior margin slightly concave distally at $2 / 3$ length, posterior lobe well developed, margin weakly crenulate, with two plumose setae proximally, somewhat flattened and angulate distally; merus posterior lobe weaker, but setae stouter than those of pereopod 6; carpus and propodus stouter than those of pereopod 6; dactylus falcate, $0.4 \times$ as long as propodus, unguis developed.

Pleon. Epimeron 1 not produced but angulate bearing one robust seta anteroventrally, posterior margin round and with three small notches. Epimera 2-3 expanded, with facial setae anteroventrally, posterior margins lined with small notches. Urosomite 1 with deep dorsal depression and mid-dorsal carina (Fig. 4A).

Uropod 1 (Fig. 4B) longest; peduncle $1.4 \times$ as long as outer ramus, with seven robust setae on dorsolateral margin and five elongate robust setae on dorsomedial margin; outer ramus with five lateral robust setae only; inner ramus $0.9 \times$ as long as outer ramus, with two medial and four lateral robust setae.

Uropod 2 (Fig. 4C) $0.7 \times$ as long as uropod 1; peduncle with two robust setae medially (distal seta stoutest) and five robust setae laterally on each dorsal margin; outer ramus $1.3 \times$ as long as peduncle, with five lateral robust setae only; inner ramus $1.1 \times$ as long as outer ramus, with four lateral and three medial robust setae.

Uropod 3 (Fig. 4D) $0.8 \times$ as long as uropod 2; peduncle $0.7 \times$ as long as outer ramus; each ramus with plumose setae on medial margin; outer ramus bi-articulate, distal article $0.2 \times$ as long as proximal article; inner ramus $0.8 \times$ as long as outer ramus, not reaching distal end of proximal article of outer ramus in position.

Telson (Fig. 4E) longer than broad, cleft about 70\%, each lobe with deep apical notch bearing one robust and one sensory seta apically, with one robust seta and one pair of sensory setae dorsolaterally.

Remarks. The subfamily Scopelocheirinae is a small group of Scopelocheiridae, composed of only eight species in three genera, united by the synapomorphy of the narrow columnar mandibular molar different from other lysianassoids (Kilgallen and Lowry 2015). In their review, the diagnosis of Aroui was restricted concerning the sharing of the unusual long, distally barbed setae on the outer plate of maxilla 2 (Kilgallen and Lowry 2015). The Korean scopelocheirid specimens in this study also show these synapomorphic characters and they are easily assigned to the genus Aroui. This genus has only four valid species: $A$. americana Lowry \& Stoddart, 1997; A. hamatopodus Lowry \& Stoddart, 1997; A onagawae (Takekawa \& Ishimaru, 2000); and A. setosus Chevreux, 1911. Aroui minusetosus sp. n. is readily distinguished from A. americana, $A$. hamatopodus and $A$. setosus in that only coxa 4 has setose margin posteroventrally (vs. all coxae 1-4 of $A$. americana, $A$. hamatopodus and $A$. setosus are densely setose 

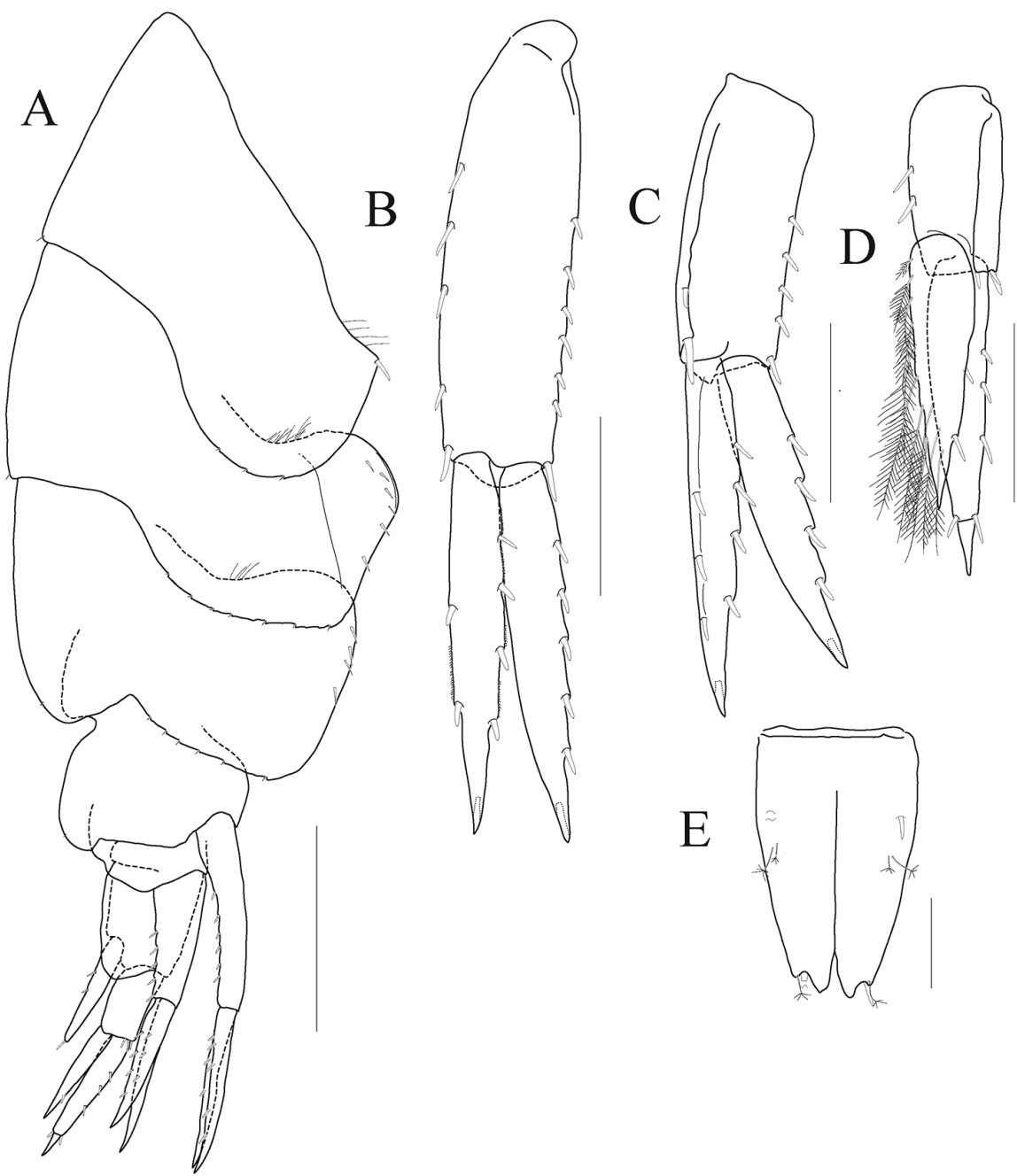

Figure 4. Aroui minusetosus sp. n., holotype male, NIBRIV0000806536, $4.3 \mathrm{~mm}$. A pleon, lateral B uropod $1 \mathbf{C}$ uropod 2 D uropod $3 \mathbf{E}$ telson. Scale bars $0.1 \mathrm{~mm}(\mathbf{E}), 0.2 \mathrm{~mm}(\mathbf{B}-\mathbf{D}), 0.5 \mathrm{~mm}(\mathbf{A})$.

ventrally). The new species is quite similar to $A$. onagawae from Japan having nonsetose coxae 1-3, but show a difference in coxa 4 : in $A$. minusetosus, it is densely setose with long setae posteroventrally, but only with a moderate setation posteriorly in $A$. onagawae. On the other hand, this new species has a less dense setation on the whole body compared to the original description of $A$. onagawae (Takekawa and Ishimaru 2000). At first, we considered the much weaker setation related to the developmental stage, but the Korean specimens show an elongated antenna 2 that indicates maturity in male, and the body length of the new species is longer than the type specimen of $A$. onagawae (Takekawa and Ishimaru 2000). Additionally, the new species shows some differences from $A$. onagawae as follows: 1 ) the eyes are ovoid and their ommatidia are 
Table I. Morphological differences between worldwide Aroui species.

\begin{tabular}{|c|c|c|c|c|c|}
\hline Characters & A. americana & A. hamatopodus & A. onagawae & A. setosus & A. minusetosus \\
\hline Eyes & poorly developed & well developed & well developed & well developed & well developed \\
\hline shape & ovoid & ovoid & pyriform & ovoid & ovoid \\
\hline size of each ommatid & large & moderate & moderate & moderate & large \\
\hline \multicolumn{6}{|l|}{ Antenna 1} \\
\hline flagellum & 9-articlulate & 9-articlulate & 13-articlulate & 10-articlulate & 8-articlulate \\
\hline \multicolumn{6}{|l|}{ Gnathopod 1} \\
\hline $\begin{array}{l}\text { length ratio of carpus } \\
\text { and propodus }\end{array}$ & $1.0: 1.2$ & $1.0: 1.1$ & $1.0: 1.1$ & $1.0: 1.0$ & $1.0: 1.1$ \\
\hline dactylus & $\begin{array}{l}\text { covered with } \\
\text { sensory setae }\end{array}$ & $\begin{array}{l}\text { covered with } \\
\text { sensory setae }\end{array}$ & $\begin{array}{c}\text { more reduced, } \\
\text { without sensory } \\
\text { setae }\end{array}$ & $\begin{array}{l}\text { covered with } \\
\text { sensory setae }\end{array}$ & $\begin{array}{c}\text { more reduced, } \\
\text { without sensory } \\
\text { setae }\end{array}$ \\
\hline
\end{tabular}

\section{Gnathopod 2}

\begin{tabular}{l|c|c|c|c|c}
\hline palm & minutely chelate & minutely chelate & minutely chelate & $\begin{array}{c}\text { minutely } \\
\text { chelate }\end{array}$ & subchelate \\
\hline defining setae & paired & paired & paired & absent & single \\
\hline Coxae 1-4 & convex & convex & straight & concave & convex \\
\hline $\begin{array}{l}\text { coxa 1 anterior } \\
\text { margin }\end{array}$ & densely setose & densely setose & $\begin{array}{c}\text { not setose in } \\
\text { coxae } 1-3 \\
\text { (coxa } 4 \text { setose } \\
\text { posteriorly) }\end{array}$ & densely setose & $\begin{array}{c}\text { not setose in coxae } \\
\text { posteroventrally) }\end{array}$ \\
\hline
\end{tabular}

\section{Pereopods 3-7}

\begin{tabular}{|c|c|c|c|c|c|}
\hline setation & moderate & moderate & densely setose & moderate & moderate \\
\hline $\begin{array}{l}\text { pereopod } 5 \text { basis } \\
\text { medial row of } \\
\text { plumose setae }\end{array}$ & present & absent & absent & absent & absent \\
\hline $\begin{array}{l}\text { pereopod } 6 \text { propodus } \\
\text { hooked setae on } \\
\text { posterior margin }\end{array}$ & present & present & present & absent & absent \\
\hline
\end{tabular}

\section{Uropod 1}

number of setae

(medial + lateral)

\begin{tabular}{l|c|c|c|c|c}
\hline peduncle & $5+6$ & $7+6$ & $14+22$ & many setae (?) & $5+7$ \\
\hline inner ramus & $0+3$ & $3+4$ & $9+11$ & $?$ & $2+4$ \\
\hline outer ramus & $1+1$ & $0+5$ & $0+10$ & $?$ & $0+5$ \\
\hline
\end{tabular}

\section{Uropod 2}

number of setae

(medial + lateral)

\begin{tabular}{l|c|c|c|c|c}
\hline peduncle & $5+3$ & $3+8$ & $10+15$ & many setae (?) & $2+5$ \\
\hline inner ramus & $2+3$ & $5+5$ & $12+12$ & $3+2$ & $3+4$ \\
\hline outer ramus & $0+3$ & $0+4$ & $0+9$ & $0+2$ & $0+4$ \\
\hline
\end{tabular}

\section{Telson}

\begin{tabular}{l|c|c|c|c|c}
\hline dorsal robust setae & one pair & absent & three pairs & absent & one pair \\
\hline Reference & $\begin{array}{c}\text { Lowry and } \\
\text { Stoddart (1997) }\end{array}$ & $\begin{array}{c}\text { Lowry and } \\
\text { Stoddart (1989) }\end{array}$ & $\begin{array}{c}\text { Takekawa and } \\
\text { Ishimaru (2000) }\end{array}$ & $\begin{array}{c}\text { Lowry and } \\
\text { Stoddart } \\
(1989)\end{array}$ & In this study \\
\hline
\end{tabular}


larger in A. minusetosus sp. n. (vs. pyriform and smaller ommatidia in A. onagawae); 2) antenna 1 flagellum is composed of eight articles in $A$. minusetosus sp. n. (vs. 13 articles in $A$. onagawae); 3) gnathopod 2 is subchelate with a small protrusion on the palm in $A$. minusetosus sp. n. (vs. minutely chelate and without protrusion in $A$. onagawae); 4) gnathopod 2 propodus has a row of four robust setae posterodistally (distal locking seta is elongate and not paired) in A. minusetosus sp. n. (vs. having a pair of locking setae in $A$. onagawae); and 5) both telson each lobes have a robust seta dorsally in A. minusetosus sp. n. (vs. three dorsal robust setae in A. onagawae) (see the Table 1, Takekawa and Ishimaru 2000). This is the first record of a scopelocheirid lysianassoid from Korean waters.

\section{Key to worldwide species of the genus Aroui Chevreux, 1911}

1 Coxae $1-4$ ventrally setose

- Coxae 1-3 ventrally smooth, coxa 4 weakly setose posteriorly or posteroventrally ........................................................................................................ 4

2 Pereopod 5 basis with an well-developed row of many plumose setae on medial surface. A. americana Lowery \& Stoddart, 1989

- $\quad$ Pereopod 5 basis with one cluster of several simple setae medially .............. 3

3 Coxa 1 anterior margin convex.... A. hamatopodus Lowry \& Stoddart, 1997

- $\quad$ Coxa 1 anterior margin concave A. setosus Chevreux, 1911

$4 \quad$ All appendages densely setose; gnathopod 2 minutely chelate

A. onagawae (Takekawa \& Ishimaru, 2000)

- $\quad$ All appendages less setose; gnathopod 2 subchelate..... A. minusetosus sp. $\mathbf{n}$.

\section{Acknowledgements}

This study was supported by the National Institute of Biological Resources of Korea as a part of the 'Survey of indigenous biological resources of Korea (NIBR NO. 201702-001)', and by the National Marine Biodiversity Institute of Korea as a part of the 'Research for the conservation and management of marine organism (2017M00100)'. We thank Prof. H.-Y. Soh and the crew of the R/V "Cheong Gyeong Ho" of Chonnam National University for their assistance in sampling.

\section{References}

Chevreux E (1911) Campagnes de la Melita. Les amphipodes d'Algérie et de Tunisie. Mémoires de la Société Zoologique de France 23: 145-285.

Coleman CO (2003) "Digital inking": How to make perfect line drawings on computers. Organism, Diversity and Evolution, Electronic Supplement 14: 1-14. 
Coleman CO (2009) Drawing setae the digital way. Zoosystematics and Evolution 85: 305-310. https://doi.org/10.1002/zoos.200900008

Dana JD (1849) Synopsis of the genera of Gammaracea. American Journal of Science and Arts, Series 2, 8: 135-140.

Kilgallen NM, Lowry JK (2015) A review of the scopelocheirid amphipods (Crustacea, Amphipoda, Lysianassoidea), with the description of new taxa from Australian waters. Zoosystematics and Evolution 91: 1-43. https://doi.org/10.3897/zse.91.8440

Latreille PA (1816) Amphipoda. In: Nouveau Dictionaire d'histoire naturelle, appliquée aux Arts, à l'Agriculture, à l'Économie rurale et domestique, à la Médecine, etc. Par une société de Naturalistes et d'Agriculteurs ( $2^{\text {nd }}$ edn). Volume 1. Deterville, Paris, 467-469.

Lowry JK, Stoddart HE (1989) The scopelocheirid genus Aroui (Crustacea: Amphipoda: Lysianassoidea) with notes on the association between scopelocheirid amphipods, cassid gastropods and spatangoid echinoids. Records of the Australian Museum 41: 111-120. https:// doi.org/10.3853/j.0067-1975.41.1989.139

Lowry JK, Stoddart HE (1997) Amphipoda Crustacea IV. Families Aristiidae, Cyphocarididae, Endevouridae, Lysianassidae, Scopelocheiridae, Uristidae. Memoirs of the Hourglass Cruises 10: 1-148.

Takekawa AT, Ishimaru S (2000) A new species of the genus Scopelocheirus (Crustacea: Amphipoda: Gammaridea) from Onagawa Bay, northeastern Japan. Zoological Science 17: 681-687. https://doi.org/10.2108/zsj.17.681

Watling L (1989) A classification system for crustacean setae based on the homology concept. In: Felgenhauer B, Watling L, Thistle AB (Eds) Functional morphology of feeding and grooming in Crustacea. CRC Press, Rotterdam, 15-26. 